\title{
Syncolostemon aurulentus (Lamiaceae), a new species from KwaZulu-Natal, South Africa
}

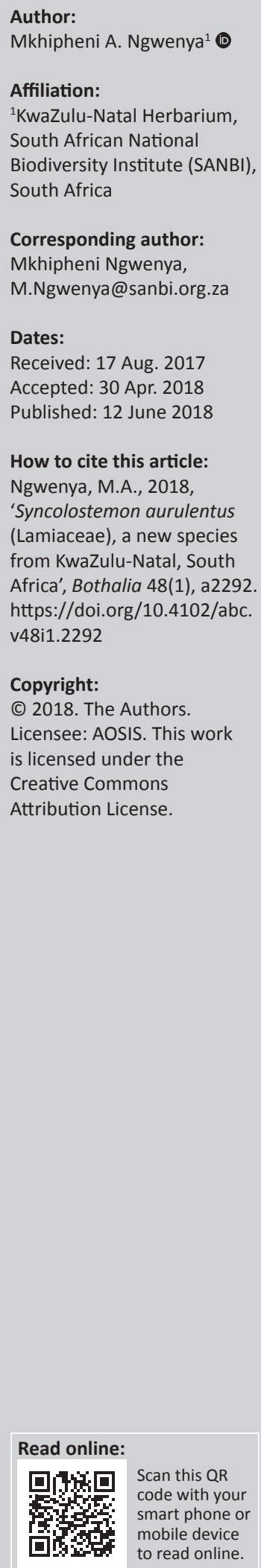

A new species of Syncolostemon E.Mey. ex Benth. (Lamiaceae) from north-western KwaZuluNatal (Utrecht), South Africa, is described. Syncolostemon aurulentus is notable in having conspicuous glittering golden glands on the leaves, bracts and calyces, which are absent in other species of the genus.

\section{Introduction}

A small population of an unknown species of Syncolostemon E.Mey. ex Benth. (Lamiaceae) was encountered during a general collecting trip to Luiperdkloof Farm in north-western KwaZuluNatal, South Africa, in 2011. This population comprised few individuals and a concerted effort to find more plants in the area proved fruitless, so it was concluded that the taxon was rare. Additional populations were found on a different part of the farm in 2014, and here plants were found to be abundant though localised.

Codd (1985) recognised nine species of Syncolostemon in his treatment of the family for the Flora of southern Africa, but this number has increased with the inclusion of the 33 species of Hemizygia (Benth.) Briq. in Syncolostemon (Otieno et al. 2006). Syncolostemon is characterised by the presence of a bilabiate or subequally 5-toothed calyx, the uppermost tooth larger than the remaining 4, broadly ovate to subrotund, tube campanulate, cylindrical, 2 lower teeth subulate to spinescent. Bracts are small and caducous or persistent, or the terminal few pairs are large and persistent as a colourful coma. It comprises annual and perennial herbs or perennial soft shrubs (Codd 1985). The genus currently includes 44 species from Africa, with the majority occurring in southern Africa, and one species from outside Africa (Syncolostemon comosus (Wight ex Benth.) D.F.Otieno from India) and one species from Madagascar (Syncolostemon madagascariensis (A.J.Paton \& Hedge) D.F.Otieno) (Otieno et al. 2006). Syncolostemon was described to accommodate material collected by J.F. Drège, and the species were separated into two groups. Group 1, containing Syncolostemon parviflorus E.Mey. ex Benth., was defined by a lax inflorescence, small flowers with calyx $<8 \mathrm{~mm}$ long and corolla tube $6 \mathrm{~mm}-10 \mathrm{~mm}$ long, and the nutlets with frill-like extensions at the base. Group 2, containing Syncolostemon rotundifolius E.Mey. ex Benth. and Syncolostemon densiflorus Benth., was characterised by a dense inflorescence of larger flowers with the mature calyx often exceeding $10 \mathrm{~mm}$ in length and the corolla tube $14 \mathrm{~mm}-30 \mathrm{~mm}$ long, and nutlets lacking frill-like extensions at the base (Codd 1976).

These two informal groups were maintained by Codd (1976) as follows: Group 1 included five species (Syncolostemon argenteus N.E.Br., Syncolostemon comptonii Codd, Syncolostemon concinnus N.E.Br., Syncolostemon eriocephalus Verd. and S. parviflorus), and Group 2 included just the two original species (S. densiflorus and S. rotundifolius).

Otieno et al. (2006) concluded that Syncolostemon s.l. is not found throughout the Afroalpine and Afromontane Regional Centre of Endemism. This is an archipelago-like area that ranges from the southern Drakensberg of South Africa through the high mountains of East Africa and north to the Simiana Mountains of Ethiopia. Within this region, the Wolkberg and adjacent Barberton centres of endemism include the highest number of species of Syncolostemon s.l. (Otieno et al. 2006).

Syncolostemon aurulentus adds to the growing number of new species that are discovered in South Africa as a result of fieldwork in areas that are not well explored.

Syncolostemon aurulentus Ngwenya, sp. nov. Type: SOUTH AFRICA, KwaZulu-Natal, 2730 (Vryheid): Amajuba District Municipality area, Emadlangeni Municipality area, (-DC), 30 Jan. 2014, A. M. Ngwenya 4326 (NH, holo.; J, PRE, iso.). 
TABLE 1: Major morphological differences between Syncolostemon aurulentus and Syncolostemon parviflorus.

\begin{tabular}{|c|c|c|}
\hline Characters & Syncolostemon aurulentus & Syncolostemon parviflorus \\
\hline Height & $250 \mathrm{~mm}-430 \mathrm{~mm}$ & Up to $1 \mathrm{~m}$ \\
\hline $\begin{array}{l}\text { Vestiture on leaves } \\
\text { and stems }\end{array}$ & Pilose & Hispidulous \\
\hline $\begin{array}{l}\text { Glands on leaves and } \\
\text { calyces }\end{array}$ & $\begin{array}{l}\text { Mixture of glittering golden } \\
\text { and dark red }\end{array}$ & Dark red \\
\hline Leaf attachment & $\begin{array}{l}\text { Petiolate, petiole } 2 \mathrm{~mm}- \\
6 \mathrm{~mm} \text { long }\end{array}$ & Subsessile \\
\hline Leaf shape & Ovate-lanceolate or elliptic & $\begin{array}{l}\text { Elliptic-obovate to lanceolate } \\
\text { or linear-lanceolate }\end{array}$ \\
\hline
\end{tabular}

Diagnosis: Syncolostemon aurulentus is similar to S. parviflorus, but differs from it by the pilose vestiture on the leaves and stems and by the conspicuously golden gland-dotted leaves and calyces. The stems, leaf margins, petioles and veins of the new shoots are noticeably purple. The style and stigma occasionally pale purple (Table 1). Bushy suffrutex, $250 \mathrm{~mm}$ $430 \mathrm{~mm}$ tall.

Stems: Several from a woody rootstock, erect to semidecumbent, branched, internodes $10 \mathrm{~mm}-70 \mathrm{~mm}$ long, lower part of stem terete, densely pilose, upper part square in section, grooved, sparsely pilose.

Leaves: Opposite, simple, erect, shortly petiolate, blade ovatelanceolate or elliptic, but some lower leaves almost orbicular, $10 \mathrm{~mm}-27 \mathrm{~mm} \times 9 \mathrm{~mm}-13 \mathrm{~mm}$, obtuse to acute, margins mostly entire, sometimes minutely toothed distally, base shortly attenuate, venation reticulate, upper and lower surfaces pilose, with mixture of dark red and prominent golden glands, petiole $2 \mathrm{~mm}-6 \mathrm{~mm}$ long, stipules 0 .

Inflorescence: Terminal, a lax panicle with lateral branches, $45 \mathrm{~mm}-100 \mathrm{~mm}$ diameter, peduncle sparsely pilose, bracts sessile, lower ones persistent, upper caducous, boat-shaped, elliptic-lanceolate, $5 \mathrm{~mm}-18 \mathrm{~mm} \times 1 \mathrm{~mm}-5 \mathrm{~mm}$, pilose and gland-dotted, margin entire; verticillasters 2-flowered, internodes $5 \mathrm{~mm}-19 \mathrm{~mm}$ apart, pedicel $1 \mathrm{~mm}$ long.

Flowers: Calyx $7 \mathrm{~mm}$ long, with tube $5 \mathrm{~mm}$ long, gland-dotted and strigose, mainly on veins, with some glandular hairs, inner surface pubescent, lobes 5, tooth-like, $2 \mathrm{~mm}$ long, unequal, pilose; corolla white, $13 \mathrm{~mm}-19 \mathrm{~mm}$ long, tube $9 \mathrm{~mm}-11 \mathrm{~mm}$ long, glabrous, abaxial lip $4 \mathrm{~mm}-6 \mathrm{~mm}$ long, sparsely ciliate, adaxial lip erect, $1.0 \mathrm{~mm}-2.5 \mathrm{~mm}$ long with purple blotch apically, pubescent and gland-dotted.

Stamens: Exserted by $12 \mathrm{~mm}$, anthers orange.

Style: Exserted by $10 \mathrm{~mm}$, bifid.

Nutlets: Two per calyx, oblong, $2.5 \mathrm{~mm}-3.0 \mathrm{~mm} \times 1.5 \mathrm{~mm}-$ $2.0 \mathrm{~mm}$, smooth, shiny, greenish brown with single dark vein on outer surface from base and with frill-like extensions at base.

Flowering time: December-January (Figure 1).

Etymology: Named for the glittering golden glands on the leaves, bracts and calyces.

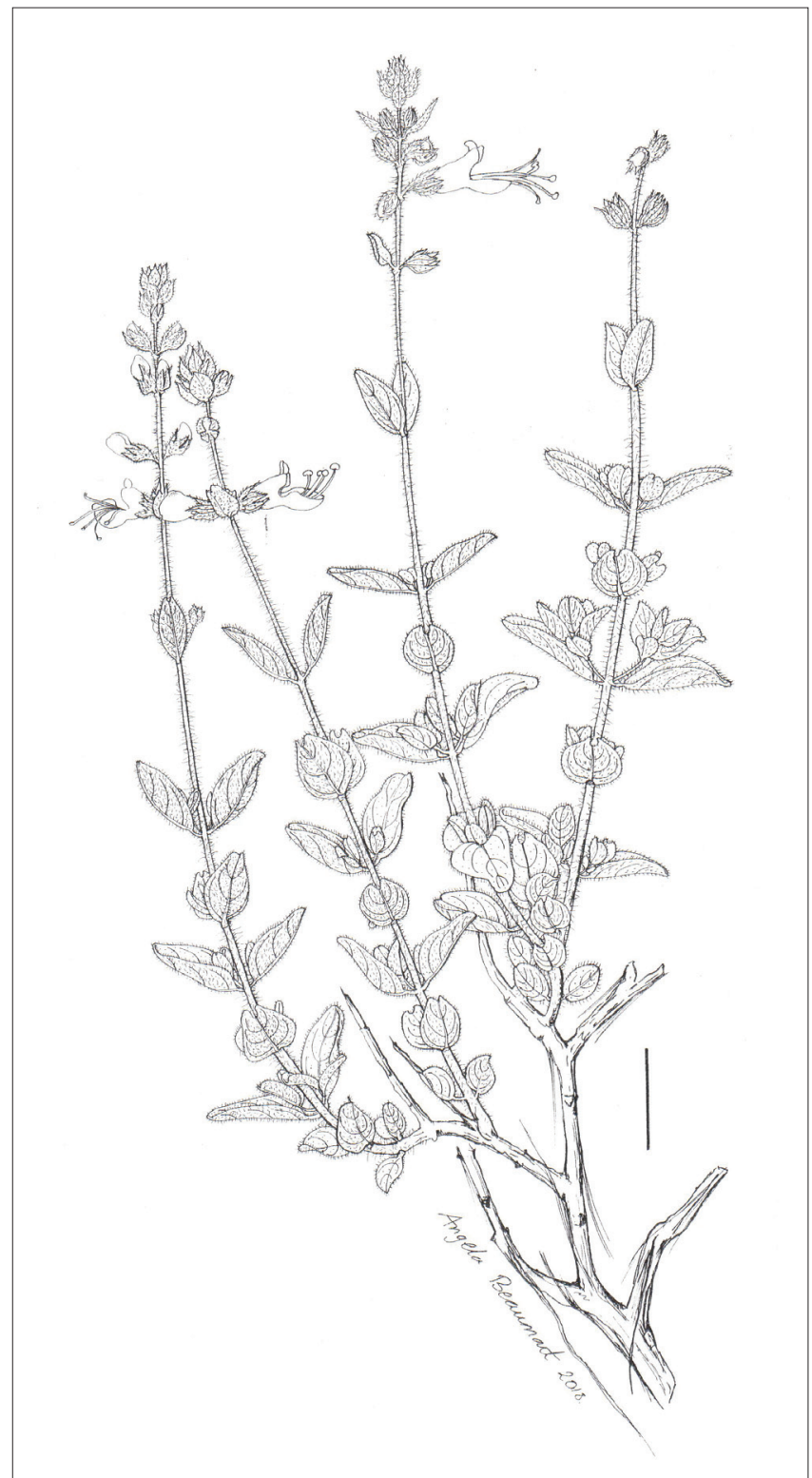

Source: Drawing of the Syncolostemon aurulentus by Dr Angela Beaumont commissioned by NH

FIGURE 1: Syncolostemon aurulentus, whole plant.

Distribution and habitat: Only known from two localities in north-western KwaZulu-Natal, South Africa (Figure 2). All five known populations are on privately owned land, three from the same area where grazing takes place. One is from the vicinity of Luiperdkloof Farm (Klipplaatdrift Farm), Natural Heritage Site No. 47, and one from Mondi's Pivaans Estate on the escarpment above Utrecht, in Amajuba District. The habitat is the Mesic Highveld Bioregion.

Vegetation type: Wakkerstroom Montane Grassland (Mucina \& Rutherford 2006). The species grows in rocky grassland and scrub on sandstone in well-drained and moist soils exposed to full sun, at altitudes of $1797 \mathrm{~m}-1864 \mathrm{~m}$.

Diagnostic characters: The leaves in S. aurulentus are strictly opposite and not clustered on brachyblasts, shortly petiolate, and ovate or lanceolate to elliptic and pilose. The leaves in 


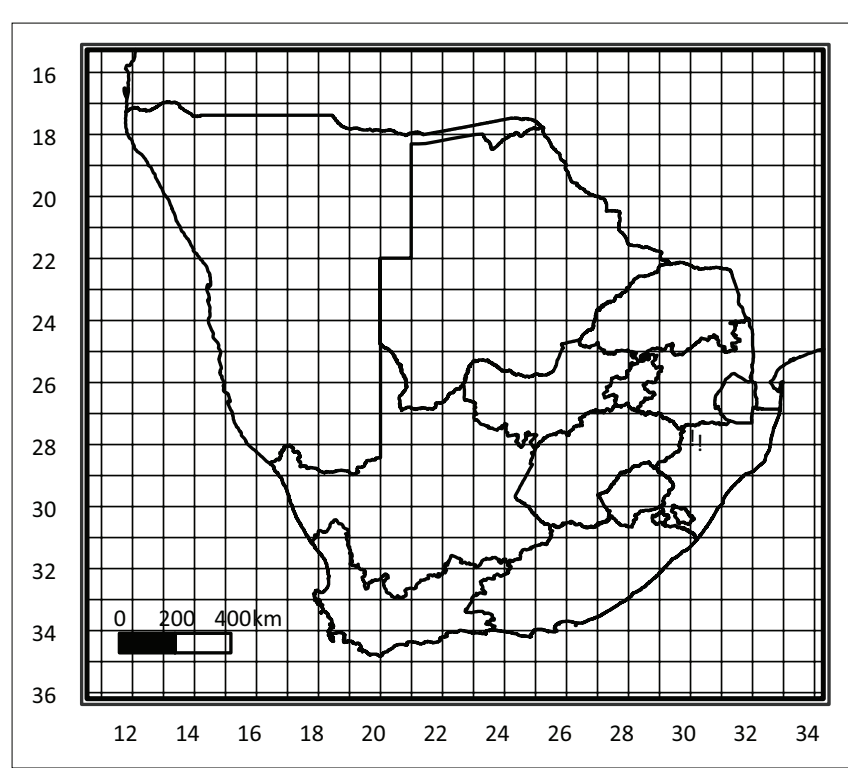

Source: Produced from SANBI's BODATSA database

FIGURE 2: Distribution of Syncolostemon aurulentus. The ! markings indicate the two localities where $S$. aurulentus was found.

S. parviflorus are often also tufted on brachyblasts along the main stem, subsessile and hispidulous to fairly densely appressed-pubescent, lacking golden glands on the leaves, bracts and calyces. It is a variable species with some plants having small leaves (12 $\mathrm{mm}$ long) and others with leaves up to $32 \mathrm{~mm}$ long. The leaves of both species are mostly entire, sometimes with a few teeth toward the apex. The corolla in S. aurulentus is white, with a few hairs on the margin of the lower lip, and the upper lip is pubescent and gland-dotted on the adaxial surface. The corolla in S. parviflorus is white or flushed with pink (Codd 1985), with the lower lip and upper part of the tube appressed-pubescent.

Syncolostemon parviflorus is recorded from the coast of southern KwaZulu-Natal inland to altitudes of up to $1800 \mathrm{~m}$, often in dense rocky grassland and in Mpumalanga. Syncolostemon aurulentus has only been found only in the Utrecht area of KwaZulu-Natal, where S. parviflorus has also been collected.

\section{Additional specimens seen}

KWAZULU-NATAL - 2730 (Vryheid): Amajuba District, Emadlangeni Municipality area, Luiperdkloof Farm, (-AD), 27 Jan. 2011, Ngwenya 3661 (NH); Klipplaatdrift Farm, (-AD), 13 Dec. 2017, Ngwenya 4573 (J, NH, PRE); Mondi's Pivaans Estate, escarpment above Utrecht, (-CB), 17 Jan. 2016, Styles 5235 (J, NH, PRE); 12 Dec. 2017, Ngwenya 4568 (J, NH, PRE).

\section{References}

Codd, L.E., 1976, 'The genus Syncolostemon (Lamiaceae)', Bothalia 12(1), 21-27. https://doi.org/10.4102/abc.v12i1.1368

Codd, L.E., 1985, 'Lamiaceae', Flora of Southern Africa 28(4), 185-191.

Mucina, L. \& Rutherford, M.C. (eds.), 2006, The Vegetation of South Africa, Lesotho and Swaziland, Strelitzia 19, South African Biodiversity National Institute, Pretoria.

Otieno, D.F., Balkwill., K., Paton, A.J. \&. Savolainen, V., 2006, 'A reassessment of Hemizygia and Syncolostemon (Ocimeae - Lamiaceae)', Taxon 55(4), 941-958. https://doi.org/10.2307/25065688 